\title{
Towards a Better Understanding of Academic Persistence among Fresh-men: A Qualitative Approach
}

\author{
Nathalie Roland ${ }^{1}$, Mariane Frenay ${ }^{1}$, Gentiane Boudrenghien ${ }^{1}$ \\ ${ }^{1}$ Université catholique de Louvain, Louvain-la-Neuve, Belgique \\ Correspondence: Nathalie Roland, Université catholique de Louvain, Place du Cardinal Mercier, 10, 1348 \\ Louvain-la-Neuve, Belgique.
}

Received: October 5, 2016

Accepted: November 17, 2016

Online Published: November 23, 2016

doi:10.11114/jets.v4i12.1904

URL: http://dx.doi.org/10.11114/jets.v4i12.1904

\begin{abstract}
Persistence in the first year at university is a phenomenon that has been studied many times. However, most research has taken a very linear view of the persistence process and little research has attempted to understand persistence by taking into account its full complexity. Yet the process of academic persistence is punctuated by striking events and critical moments that may interact with the characteristics of the student and his environment and then have some influence on persistence. In this perspective, a qualitative study was conducted to better investigate the process of persistence. This study confirms the idea that persistence is a more complex phenomenon than it had previously seemed and shows that there are different pathways resulting in students persisting or dropping out.
\end{abstract}

Keywords: academic persistence, qualitative approach, student trajectory, striking moments

\section{Introduction}

\subsection{Research on academic persistence}

Academic persistence has been extensively studied in the literature and many researchers have tried to understand this phenomenon by identifying its determinants (Burrus et al., 2013; Kuh, Kinzie, Buckley, Bridges, \& Hayek, 2006; Otero, Rivas, \& Rivera, 2007; Pascarella \& Terenzini, 2005; Schmitz, Frenay, Neuville, Boudrenghien, Wertz, Noël, \& Eccles, 2010). This interest in the factors underlying academic persistence can be explained by the high freshman year drop-out rates at university, with over 25\% of students giving up their studies (National Center for Education Statistics [NCES], 2005; Organisation de Coopération et de Développement Economiques [OCDE], 2013). Persistence may be considered as a process that occurs throughout the year and results in a variety of different behaviors (e.g., attendance at lectures and practicals, time spent studying during the week or during the weekend) whose the most used in the literature is the student's registration a year afterwards in the same field of studies (Neuville, Frenay, Noël \& Wertz, 2013).

In the early research, academic persistence and dropout were seen as dependent on the student's personal characteristics (e.g., skills, past performance, willingness) (Kuh et al., 2006; Tinto, 2006). Students who dropped out were blamed and were considered to be solely responsible for their failure. This view of persistence changed in the 1970s as a result of educational models which highlighted the role played by the environment, particularly by the institution, in the process of persistence (Bean, 1985; Tinto, 1975, 2006). These models, the best known of which are those of Tinto (1975) and Bean (1985), suggest that persistence results from a longitudinal process of interactions between the student and the academic and social systems of the institution (Schmitz et al., 2010; Tinto 1975, 1997).

These educational models emphasize the importance of institutional and social experiences in the transition between secondary and university education, but also the importance of a suitable fit between personal and institutional characteristics (Braxton, Hirschy, \& McClendon, 2004; Schmitz et al., 2010; Tinto, 1997). Dropout results from a lack of congruence between the student's characteristics and those of the chosen institution (Cabrera, Nora, \& Castaneda, 1993; Kahn \& Nauta, 2001). According to these models, a student enters college with a set of predispositions consisting of his personal, familial and educational characteristics, his goal commitment and his institutional commitment (Bean, 1985; Tinto, 1975). These features influence the experiences that the student will live through and determine his degree of academic and social integration (Braxton, Sullivan, \& Johnson, 1997; Cabrera et al., 1993; Pascarella \& Terenzini, 2005). The concept of integration underlies these models and many studies have shown that social integration is one of the most important determinants in the persistence process (Braxton et al., 1997; Pascarella \& Terenzini, 2005; Schmitz 
et al., 2010). Academic integration is measured, first, in terms of the academic performance and intellectual development of the student and, second, by the student's identification with the academic system's norms, that is to say, the degree of congruence between the student's values and goals and those of the institution. Social integration is defined by the interaction between the student and the protagonists of the educational system (teachers, peers...) and is measured by the degree of congruence between the student and the social environment of the institution. Negative experiences tend to reduce the degree of integration, to create a distance between the student and the academic and social systems of the institution and to promote disengagement. Tinto (1975) insists that the quality of experiences in the academic and social systems (measured by the degree of academic and social integration) modifies the initial commitments of the student ("goal commitment" and "institutional commitment"). These commitments determine the intention to persist and overall persistence. We should also note the importance of environmental factors, such as social support, on academic persistence (Bean, 1985). The crucial role of social support is consistent with a social networks perspective that college students' relationships with faculty and peers as well as with family, old friends, and mentors all contribute to student persistence (Astin, 1993; Kuh et al., 2006; Pascarella \& Terenzini, 2005; Tinto, 1997). According to Holahan and Moos (1981), family support can play a significant role in helping young adults to successfully adapt to college by buffering the negative effects of transition. Similarly, Kalsner and Pistole (2003) found that perceptions of insufficient social support have been linked with student dropout.

Alongside the development of these educational models, motivational models have emerged. Although these models were initially seen as competitors of educational models, they are now considered to be necessary and complementary to the educational models in gaining a better understanding of academic persistence. Motivational and educational models are now often used together in order to furnish a more complete picture of the persistence process (Burrus et al., 2013; Cabrera et al., 1993; Kuh et al., 2006; Robbins et al., 2004; Sandler, 2000). These motivational models focus on the prediction of behavior or behavior changes by taking into account factors such as motivation, task value, self-efficacy and the aims pursued. According to several researchers, the expectancy-value model is particularly relevant to understanding and predicting academic persistence (Robbins et al., 2004; Schmitz et al., 2010) as well as to predicting intention to persist (Neuville, Frenay, \& Bourgeois, 2007). The theory of "expectancy-value", developed by Eccles and Wigfield (2002), closely links performance, persistence and choice to people's expectations and beliefs concerning the value of the task. This theory suggests that students' perceptions regarding their probability of success in a given task (expectancy perceptions) and their perceptions of what the task can bring them (value perceptions) are the most immediate determinants of behaviors related to learning such as the choice to engage and/or to persist in performing a task, the learning strategies that the student will implement to approach this task and, finally, performance. According to this model, an individual will tend to orient himself towards and choose those activities for which he has high expectations of success and to which he attaches great value. Expectations and values are assumed to be positively connected (Gao \& Xiang, 2008; Wigfield \& Eccles, 2000). Eccles and Wigfield (2002) consider the perceived value of the task to be the subjective perception about what the task can bring. These authors identified four components of value. The value associated with success (or importance), the intrinsic value (or interest), the extrinsic value (or utility) and the cost. The first three components have a positive impact on the value, while the cost has, conversely, a negative effect. Eccles and Wigfield (2002), define expectations of success as people's beliefs about how they will carry out a task. Expectations are determined by the individual's perception of the difficulty of the task and the perception of his skills in a given field. Expectations of success are close to the concept of self-efficacy belief, developed by Bandura, which is defined as the beliefs an individual has in his abilities to organize and use the different means required to achieve a certain level of success (Bandura, 1997).

\subsection{Limitations of Previous Research}

\subsubsection{Critical Moments in the persistence Process}

These different research approaches and theoretical frameworks regarding persistence have rarely been rooted in a time perspective which would take the academic progress of the freshman into account (Wasylkiw, 2016). However, several authors in educational science have shown that the first year at university is punctuated by pivotal and decisive moments. It is at these times that persistence is sometimes questioned (Astin, 1993; Briggs, Clark, \& Hall, 2012; Hurtado, Carter, \& Spuler, 1996; Upcraft \& Gardner, 1989; Wasylkiw, 2016). For example, some authors have shown that the first weeks at university are extremely decisive for the student's trajectory in the program (Astin, 1993; Hurtado et al., 1996; Upcraft \& Gardner, 1989; Wasylkiw, 2016). It seems that arrival in a new educational system is a major event which is associated with high levels of stress (Holmes \& Rahe, 1967). Another key moment often discussed in the literature concerns the announcement of exams results. Indeed, it seems clear that exam failure calls into question the student's choice of studies and thus the persistence in those studies (Roland, De Clercq, Dupont, Parmentier, \& Frenay, 2015). It is no coincidence that most academic interventions offered by universities take place either preventively at the beginning of the academic year or as remediation after exam periods (Salmon, Houart, \& Slosse, 2011). In addition to 
these key academic moments, it seems relevant to hypothesize that personal life events may also disrupt the student's progress. This perspective has not really been considered in the literature (Wasylkiw, 2016), which reveals a significant dissociation between the academic sphere and the private sphere. However, it seems that life events affect the well-being and the involvement of people in many different spheres of their lives (Holmes \& Rahe, 1967; Ogden, 2010; Papalia \& Feldman, 2014). So it is reasonable to suppose that it may therefore affect the academic progress.

Given the importance these key moments and life events seem to have on the persistence process, it therefore seems essential to examine them further in relation to persistence.

\subsubsection{The Complexity of Academic Persistence}

The many existing theoretical models explaining persistence and the diversity of determinants of persistence that arise from them, allow us to account for the complexity of the phenomenon of persistence. However, despite this diversity, most studies tend to assume that there is only one way to persist or give up and that students therefore all follow the same "path". They simplify a phenomenon that in fact seems to be complex (Briggs, et al., 2012; Wasylkiw, 2016). However, a few qualitative studies (Roland, Boudrenghien \& Frenay, 2015; Wasylkiw, 2016) on the subject report that persistence results from a combination of factors but that this combination varies from person to person depending on the situation he encounters and the event(s) he experiences. So there is not only one way to persist or to give up; rather, persistence is a much more complex phenomenon.

It therefore seems essential to continue to explore the issue of the complexity of the persistence process in order to better understand this multifaceted phenomenon.

\subsection{Purpose of Our Study}

Despite the abundant literature on academic persistence, most research has taken a linear view of persistence and does not take into account the different critical moments that form the pattern of a year and can affect student persistence. The first year of college is far from being a bed of roses and it seems that a number of key moments may adversely affect or enhance student persistence (Astin, 1993; Briggs et al., 2012; Hurtado et al., 1996; Upcraft \& Gardner, 1989; Wasylkiw, 2016). However, no study has attempted to identify clearly those moments. This is probably due to the kind of studies carried out. Indeed, most studies of persistence have used quantitative approaches. Such an approach does not allow explanation and identification of the persistence process. In order to do this, qualitative studies seem necessary (Tinto, 2006; Wasylkiw, 2016). An awareness of these critical moments will make it possible to better understand how they affect the process of persistence and also to identify which determinants motivate students to persist or drop out at these pivotal moments. We might also try to see if these determinants have the same role and the same influence at all periods of the year.

In addition to the key moments of an academic year, we would also like to identify the personal life events that can disturb the student's academic progress. This is an issue that has not been discussed in the literature. However, it has been proven that life events affect various aspects of a person's life, and therefore the academic sphere as well (Ogden, 2010; Papalia \& Feldman, 2014). We would also like to see how these life events affect the academic progress of a student and to identify what leads a student to continue or give up his studies during these life events.

Finally, to appreciate better the complexity of the persistence process, we wish to identify the possible interactions between the determinants of persistence and their possible joint influence on the student's progress, particularly during critical moments and life events. Current research takes little account of the possible interactions between determinants (Wasylkiw, 2016). We question whether these interactions are present and what influence they have on the student's progress.

To achieve our different goals, we carried out a qualitative study which allowed us to approach more closely the complexity of the persistence process in its temporality. Indeed, the lack of consideration for a time perspective and for the various key moments is probably due to the small number of qualitative studies into persistence that have been carried out (Tinto, 2006; Wasylkiw, 2016). Our qualitative approach explored persistence processes occurring during an academic year based on student experience. Such a design could allow for an in-depth investigation of the factors entangled in the persistence process and of their interrelations across the academic year (Willig, 2013).

\section{Method}

\subsection{Participants}

Semi-structured interviews were conducted with 15 students (11 female / 4 male), from a French-speaking university in Belgium, enrolled the previous year in first year psychology. These students had different academic paths. The aim was to collect various testimonials. Thus, in 2013 some of the participants had successfully completed their first year $(\mathrm{n}=$ $10)$, whereas others had failed $(n=5)$. Among these students, some had decided to continue their studies in psychology 
$(\mathrm{n}=12)$, while others have decided to stop $(\mathrm{n}=3)$, independently of whether they had passed or failed. Table 1 provides a description of the participants in our sample.

Table 1. Description of participants

\begin{tabular}{llll}
\hline Participants & Gender & Success or failure in 2013 & Persistence or dropout in 2013 \\
\hline A01 & Male & Success & Persistence \\
A02 & Female & Success & Dropout \\
A03 & Female & failure & Persistence \\
A04 & Female & Success & Persistence \\
A05 & Female & Success & Persistence \\
A06 & Female & Failure & Dropout \\
A07 & Female & Success & Persistence \\
A08 & Male & Failure & Persistence \\
A09 & Female & Failure & Persistence \\
A10 & Female & Success & Persistence \\
A11 & Female & Success & Persistence \\
A12 & Female & Failure & Dropout \\
A13 & Female & Success & Persistence \\
A14 & Female & Success & Persistence \\
A15 & Male & Success & Persistence \\
\hline
\end{tabular}

\subsection{Procedure}

We contacted by email students with different paths in terms of achievement and persistence. Selection was made randomly. Students were of course free to agree or not to our request and were assured of the confidentiality of their responses.

Semi-structured interviews were carried out from October to December 2013. They lasted on average 25 minutes and were recorded. They were then transcribed, based on the recommendations of McLellan, Neidig and MacQueen (2003). The interviews were conducted by the first three authors of the present article. They took place in the researchers' office. To carry out these interviews, an interview protocol was developed following the recommendations of Blanchet and Gotman (2010). To begin, we explained briefly to participants the purpose of the study and its ethical considerations (e.g., freedom to stop the interview at any time). Then we presented participants with Leclerc-Olive figures (1997), which represented different possible trajectories through a year. Based on these figures, the participants were invited to draw their own trajectory for the previous year (2012) (both personal and academic). This drawing was the basis for the discussion and for the sharing of their academic experience. Our goal was to understand how what happened during the year had more or less influence on their academic choices. The exchange between the participants and the interviewer was quite free, but punctuated by follow-up questions (De Ketele \& Roegiers, 2009). The purpose was to address "what" and "how" questions so as to better understand the participants' experience. To conclude the interview, some classic questions were put to the participants (e.g., "Are there elements of your course that have not been addressed and which you would like to share?").

\subsection{Data Analysis}

We analyzed the participant's trajectory through two types of analysis: thematic and sequential analyses. To identify variables related to the persistence process, we used thematic analysis via meaning units. This method of analysis brings together information gathered during interviews on several central themes related to the research problem (Paille \& Mucchielli, 2012). A theme can be regarded as a minimum meaning unit (Creswell, 2003). Specifically, thematic analyses aim to categorize and describe data (Braun \& Clarke, 2006).

To understand the time sequence and when and how the identified themes were involved in the persistence process, we performed sequential analyses. To do this, we first created a sequential summary of each interview. The aim was to arrive at a description of the different events experienced by participants while respecting their temporality (Fischer \& Wertz, 1975). We then compiled tables that allowed us to get an overview of all participants' trajectories and to find similarities between students in terms of academic progress.

Although thematic and sequential analyses were conducted in two stages, the results of these two types of analysis will be presented jointly in order to gain a better overview of the persistence process.

\section{Results}

First we will present the critical moments of an academic year as reported by participants. These are the moments that punctuate the academic progress of all students and that seem be emotionally charged. We will discuss how these moments are experienced by students, but also the influence of determinants that enhance, improve or transform the emotional impact of these moments. 
We will then present the life events that were reported by some participants. We will focus on their experiences of these life events, and also on the impact they have had on the academic progress of students. Finally, we will identify the determinants that enhance, improve or transform the emotional impact of these moments.

Finally, after identifying and defining critical moments, we will analyze the academic year as a whole and try to identify the role of each determinant. We also will try to see if the combined presence of different determinants can explain persistence or dropout among students.

\subsection{Analysis of the Experience of Critical Moments in the Academic Year}

\subsubsection{Starting University}

Starting university is a turning point for many students. It is associated by some of them (46\% of the participants) with excitement and envy, as explained by A06: "Well, so, at the beginning of the year I was really motivated. I told myself that I was going to give everything to try and succeed, so I was going to classes and, I was studying at home." In the same vein, A09 says: "In fact, to begin with I was super-motivated. I did a year of medicine before and I had no life, I did nothing but study. So I came here super-motivated. I had the feeling a little of coming back to life." For other students (53\% of the participants), starting university is associated with apprehension and anxiety regarding courses, integration or more generally with a fear of the unknown. In this context, A04 says this: "So, well, at the start I wasn't so good, because I was really afraid of what was waiting for me at college and, er, of the teachers' expectations, of seeing a lecture theater with 600 people when you're used to a class of 24 with contact with the teacher, etc." Finally, A11 also shares the concerns of other students, as she explains here: "When I got here I was totally alone and I had to fit in, study, succeed right away. All my brothers and sisters have failed at university so I went off telling myself that I'd never succeed either."

The students' feelings about starting college appear to have been influenced by several key factors, namely interest in the course, social integration and social support.

Several students (40\% of the participants) reported that the sometimes negative experiences of starting university was improved thanks to the interest they had in their courses, as evidenced by A02: "It was the beginning, finding out about things you didn't know, all that stuff. So, not easy. Then it got better because, all the same, I liked the classes at the beginning, because they were interesting, I liked to go along." For some students (20\% of the participants) starting college was very positive, but they quickly became disillusioned because of their lack of interest in the course program, as evidenced by A06: "At the start of the year, I was super-motivated. And then, from a certain point, I began to get demotivated, I started to get bored. In the end the thing is that in the first year you mainly have general classes, and that didn't interest me very much so I was a little disappointed with what I was seeing."

Social integration also seems crucial to overcoming the difficulties of starting university, as some students related. Indeed, students who quickly made friends had a much better experience of starting university (33\% of the participants). In addition, they were more motivated to attend classes, as shown by A01: "So, at the beginning, I didn't really know too much about how things were at college, but it was cool because I was getting to know quite a lot of people and so I felt better and better in the lecture theater and so that motivated me a little to follow classes more." This statement may be added to that of A02, who in her first year at university struggled to integrate, like some others of our participants (33\% of the participants), and who reoriented after the first year. She explained that the beginning of her second year was much easier and more motivating through meeting people with whom she got on, as illustrated in this excerpt : "Also, I met people I get on really well with more easily than in the previous year, when it took me two or three months to meet people who were really nice. So that motivated me to go to classes."

Like social integration, support seems very important at the beginning of the academic year in helping students overcome the stress of this transition (75\% of the participants). A04, who was very stressed and disappointed about courses at the beginning of the year, was able to rely on her family to remotivate her: "You see, it was especially my family, my sister who was also crazy about studying I mean, and who also experienced a little this kind of period when she was at college, who especially gave me advice." Conversely, A12 is a student who had a difficult beginning of the academic year because she failed her first year and did not have the necessary support from her mother who wanted her to leave university: "Well, my mother wanted me to go to Marie Haps [non university education]. In fact, in my second freshman year I went to Marie Haps for a week. I went to have a look and took classes and then I enrolled but straight away I didn't like it at all and, well... I didn't want to go back but it was a little bit my mom who made me and I really had to make a decision because we were getting into October..."

\subsubsection{The Exam Sessions}

The examination periods are also key moments for students and are for some synonymous with high levels of stress (82\% of the participants) which can even affect their session, as evidenced by A04: "The first January session, in terms of 
stress, it was really huge. I've never experienced a session as stressful as that. I really didn't feel good, in the end I was having anxiety attacks and everything. Above all, it was fear of having my first failure." This stress is present for the different exam sessions, but seems more acute with the January session since this is their first examination session.

The stressful experience of exam sessions appears to have been influenced by three key factors, namely, interest in the courses, self-confidence and social support.

Several students (33\% of the participants) reported that interest in their courses helped them to move forward and to overcome difficulties in their examination session. This is particularly the case of A04, a student who had a bad experience of her exam sessions because of the stress she was struggling to manage: "For me it was obvious that I was going to carry on and in any case I was certain of it. But it was more the stress of having to put up with this second session that was hard to take. But in itself, about having a successful year and wanting to continue my Psych studies, I never had any doubt about that. The more the year went on the more classes I had and I realized that I really liked what they were giving me and so that also reassured me about my choice." Conversely, A02, a student who also felt some pressure during the exam sessions, realized that she had little interest in her courses, which made this session more difficult to: "I was really feeling the pressure. As well, I had more exams in the second semester. I remember when I was taking an exam a girl asking me 'and why are you taking Psych?' I almost didn't know what to reply, I wasn't even sure. And I noticed that I wasn't managing to get down to it because I really didn't see any point."

Self-confidence also seems important in overcoming the stress of the exam sessions. Thus, the first and very stressful examination session allowed some students (20\% of the participants) to gain some self-confidence, which in turn allowed them to take a calmer approach to the next exam session, as A04 explained: "It all went much better in the June exams, although I had a shorter study break and more exams, so... I think that the first session was really a test. And I think that after the January exams I stayed, I think, pretty confident about it all." In contrast, for other students $(20 \%$ of the participants), the session was more difficult, especially because of a lack of confidence. As A14 says: "During the study break it [motivation] falls a bit because my confidence isn't high... I ask myself 'am I going to make it?', so it's not always straightforward, it's not an easy time either, er, there's lots of stress."

Finally, support also seems very important. For example, some students ( $40 \%$ of the participants) report that without the support of those around them they would have struggled to overcome the stress of the exam sessions. As A06 explained: "Well, she [her sister] called me really every day and she motivated me. She gave me encouragement, she told me the news and she reassured me a lot. She was there, so that really helped me a lot." Finally, other students (20\% of the participants) had no opportunity to benefit from this support. This made their sessions more complicated, as A04 explained: "Well, in the end, it's a bit complicated because my college friends, all the friends I'd made in freshman year, didn't study at all and had no motivation at all, so I really didn't get any reassurance, if you like."

\subsubsection{Exam Results}

Finally, exam results represent another critical moment that can affect student motivation. For some (27\% of the participants) it is a time of relief and joy while for others disappointment and discouragement prevail (53\% of the participants). A01 shows his joy at the getting his results: "I'd done really, really well. So I was pretty motivated, yeah, and so I was all fired up when I started again. That encouraged me, eh, to carry on at the same level. I told myself it would be stupid, when I had really good scores for now, well, to tell myself I was going to give it up. Really, it made it possible for me to be even more motivated for what came after." In contrast, some students were very disappointed with their results. This is particularly the case of A10, who says: "And then I got demotivated all at once because I'd failed quite a lot of exams in January, I'd failed three out of five and, well... afterwards, well, I went through a pretty tough time. I said to myself, 'Is this really what I want to do' I did some pretty serious self-analysis.” Finally, A14, a student who failed her year, says this: "It was really tough for me to accept having to start my freshman year again. Well, so it was a really bad experience for me and that showed in my personality. I was touchy and stuff like that. And I didn't commit to studying, so when I had classes to retake in my freshman year, well, eh, I went along but I didn't feel involved in what was going on."

The feelings of students following their exams results seem to have been influenced by several key factors, namely interest in the courses, self-confidence and social support.

For some students (47\% of the participants) who had unsatisfactory exams results, it was interest in their courses that allowed them to stay motivated. This is particularly the case of A13, who had unsatisfactory results and failed his year but remained motivated thanks to his interest in the course: "So, you see, Psychology, in terms of my personality, it was really something that suited me... and I really couldn't see myself doing anything else. " In contrast, A06 failed to regain his motivation after his poor results because of the lack of interest she had in classes: "And then, my results, well I'd had five exams I think in January and I'd only passed two of them. So I was really demotivated and then it was total free fall or something. I stopped going to classes, I had nothing to do with them any more. Especially because the 
second semester courses were Neurophysiology, Law, Economics and all that kind of stuff, and so they really weren't classes that interested me."

For students who faced failure in one or more exams, we observed that continuing to have confidence in themselves allowed them to remain engaged in their studies (27\% of the participants), as shown by the testimony of A07: "Well, afterwards I think you need to have some faith in yourself and tell yourself that just because you fail once doesn't mean you'll fail all the time." For other students (13\% of the participants), confidence was not strong enough for them to overcome failure and continue their studies, as explained by A12: "In fact, I'd begun to doubt my ability, because I've always told myself: 'In any case, it's because you don't study enough.' And for me, it was outside factors. And in the end, I really gave myself a bit of a slap, telling myself: "wow, you've done your freshman year twice and you still can't manage to pass."

Support was also very useful for students who received disappointing results (33\% of the participants) as in the case of A04: "I think it's really super important to have people around who motivate us because when you're up against it, it's tough to tell yourself: 'Well, I can manage it anyway, I'll give it my best shot, as if nothing had happened.' But for me, in my particular case, well it was when things really weren't going well or at the beginning of the year when I was a bit disappointed when I didn't get the classes I was expecting, well it was really my relatives, my family and friends who supported me." However, although this support had positive effects for most students, it was felt by some to be pressure to continue their studies, which was not always been a good experience (20\% of the participants). As A06, who had begun to give up because of his results in the January exams, explains: "I think it was mainly my friends who got me to continue going to classes and to work, and then they made me feel a bit guilty, like 'What are you doing ? You've still got to work, come to the library with us', and that kind of stuff. So it's true that I couldn't stay at home doing nothing any more, I felt too guilty and my parents were paying the fees as well, I had to put myself into it, so perhaps it was more for other people that I really carried on trying. And there as well, it's really my father who succeeded in motivating me. And inevitably in the vacation when I told them I wanted to give up, once again he tried to persuade me."

\subsection{Analysis of Experience of Life Events}

For some students ( $20 \%$ of the participants), pivotal moments of an academic year were interspersed with life events that affected their academic progress. These life events may be called negative and they disturbed the students' academic motivation. This is particularly the case with A05, who explains: "I felt really down starting the year again. Another reason I was really low is that my father was in a coma in fact just at that time. And the courses I'd failed, I could have passed, but it wasn't possible in the state I was in. Then afterwards my father died. Then, I don't know, until January more or less things didn't go too well." A12 was also confronted with the loss of relatives, as she explains: "And then in November I lost my godfather so that wasn't an easy time. Then, er... I lost my grandparents one after the other so suddenly it was a little test which made me doubt myself a bit and then I worked..." Finally, A07 encountered health problems during her year: "I'm a pretty delicate person and then I had lots of kidney problems, er... I spent a bit of time in hospital, so, er, it was tough, I wasn't motivated... " Although positive life events may also have had an impact on the academic progress of the participants, they did not mention them during the interviews.

Students reported that two elements were crucial in overcoming these life events and in finding motivation related to study. These are interest in courses and social support.

Interest in courses was a key determinant in rediscovering a taste for study for some students (13\% of the participants). A05, who had faced the loss of a loved one, reported this: “And then, I don't know, at a certain point something clicked and I told myself that I mustn't let myself go, I had to continue Psych, to start going to classes again, because I liked it. And so I really held on to this outlook, telling myself that that was what I wanted to do no matter what happened and whatever problems I might meet. Well... I pictured myself in the future and I saw that that was what it was really about."

Faced with difficult life events, support from relatives also seems useful in helping students to stay motivated in their studies (20\% of the participants). A05 says that after the loss of her father she did not feel supported and says she had more trouble moving forward in her studies: "Perhaps I didn't have support from family anymore. Things could have got better more quickly, but, there are you are, I had to do it all on my own. Unfortunately, my family was a bit complicated at the time because my parents were separated and as my father died, well... so my mother wasn't very keen to talk about it. My stepfather wasn't a great favorite either. I never saw my brother because he was in Brussels. So I only had my boyfriend." However, she explained that when she managed to turn to others, the support she received was beneficial to her well-being and her academic progress: "At that time I was pretty much on my own, because I'd closed in on myself over the course of the year. Then, at a certain point, I started seeing people again that I hadn't been seeing. Human contact was a big help in taking myself in hand and in remotivating me." In the same vein, A07 says that the support of her friends and family was very useful during her health problems: "After my health problems I had my 
friend, who helped me a lot. He's right behind me, my parents too. I think that it's thanks to family and friends that I've succeeded in moving forward."

\subsection{Analysis of the Weight of Each of the Determining Factors and of Their Combined Effect}

The results of this study as they have been presented so far have allowed us to identify not only the key moments of an academic year as well as the individual's experience of them, but also the factors that modify the experience of those moments. We were however not interested yet in the weight and role of these factors in the persistence process. First, we observe that both interest and support are present in every emotionally charged moment of the persistence process. They therefore seem essential to persistence. Self-confidence in turn plays a role during exam periods and during the announcement of exams results. Finally, the influence of social integration is mainly seen at university entrance. These four determinants seem essential to the student's persistence process. They allow us to see students in perspective with themselves (self-efficacy), with others (integration and support) and with their studies (interest). These factors therefore have different roles.

However, the absence of one of them does not necessarily jeopardize student persistence. This is explained by the fact that the absence of one factor appears to be overcome by the presence of another. Our analyses have indeed proven that interactions between factors may influence the way students live the different key moments of the year. So if one factor is missing but is compensated for by another, the student will usually be able to persist. We will present the observed interactions between these factors in the participants of our study and the effect of these interactions on their persistence, regardless of when they occur during the year.

In the previous section, we observed that interest in study seemed essential to getting through the key moments of the year, whatever they are. Conversely, a lack of interest made academic progress more difficult. However, joint analyses show that if a student feels a lack of interest at some point, but feels otherwise integrated and supported, it will be easier for him to overcome any difficulties and he will persist (cf. A01 and A10). Our findings also show that students who have lost interest in their study program and who do not feel supported and/or integrated fail to maintain their commitment to their studies in case of difficulties and tend to give up (cf. A02 and A06). Thus, to compensate for a lack of interest, integration and/or support seems essential to persistence.

We also observed that self-confidence was a key factor in coping with the critical moments. Low self-confidence sometimes made the students' academic life more difficult. However, our joint analyses indicate that students with low self-confidence somehow manage to overcome difficulties and to persist if they demonstrate a significant interest in their studies and if they feel supported (cf. A04, A08, A11 and A14). In contrast, students with low self-esteem who do not have interest and/or are not supported are less able to override difficult moments and more easily give up their studies (cf. A06 and A12). To address the lack of self-confidence, high levels of interest and support seem necessary to persistence.

Our early results also indicated that social integration was very important and that students who felt poorly integrated were those who had the worst experience of university entrance. Social integration especially had an effect on their attendance at lectures, on their well-being ... However, our joint analysis shows that students who feel poorly integrated manage to stay motivated through difficult moments and to persist if they receive social support (cf. A05 and A14). This support probably allows them to compensate for the lack of integration. Conversely, students who feel poorly integrated and who are not supported encounter more difficulties in overcoming obstacles and tend to give up (cf. A02, A06 and A12). Thus, a lack of integration seems to be compensated for by the support of friends and family and thus leads to persistence.

Social support also seems very important for students in helping them to get through difficult moments. Our first results indicated that without this support, the student's progress was more complicated. However, based on our joint analysis, it appears that students who lack social support, but have enough self-confidence, manage to bypass the difficulties and persist (cf. A04). Conversely, students who do not feel supported by their families and friends and who do not have self-confidence will have more difficulties in getting through difficult moments and will be more likely to drop out (cf. A05 and A12). Thus, a lack of support can be compensated for if it is associated with self-confidence, which will promote student persistence. We caution that support, although it appears to be beneficial when present, can be felt as a social pressure that is sometimes resented by students. Students who experience this social pressure but who are integrated and interested in their studies still manage to maintain their motivation and persist (cf. A03). In contrast, students who feel this pressure, but are not integrated and interested in their studies, are less able to persist (cf. A02 and A06).

\section{Discussion}

This qualitative study allowed us to identify the key moments that punctuate an academic year. Hitherto, little research 
has tried to identify these key moments. These key moments do seem to have an impact on the student's progress. These moments are striking because they are associated with significant emotional experiences. Starting university is a very exciting time for some students but it can also be very stressful for others. Exam periods are the second noteworthy moment and are experienced by many students as a significant source of stress. Finally, exam results are another pivotal moment for the students and they are associated with disappointment or joy. Our analyses allowed us to see that the experience of those moments varied from person to person but also that every moment was associated with a specific feeling. This finding allows us to emphasize the diversity that exists in the persistence process.

Our analyses also revealed the occurrence of life events for some students. These events appear to have played an important role in their academic progress. In the literature, life events are considered as stressors that can also generate a set of emotional responses (Holmes \& Rahe, 1967; Moos \& Swindle, 1990; Ogden, 2010). These emotions, depending on how they are regulated, will affect the student's academic progress (Graziano, Reavis, Keane, \& Calkins, 2007).

These striking moments and these life events are, as we said, emotionally charged. The way they are experienced seems to have an influence on the student's courses. But little research has used emotions to understand the students' trajectories of persistence. Only a few studies have included stress in their studies on persistence (Sandler, 2000; Torres \& Solberg, 2001). Stress can be harmful in some cases ("distress") by draining students' resources, but in other cases it can be beneficial ("eustress") by enabling students to surpass themselves (Bean \& Metzner, 1985; Ogden, 2010). However, other emotions have received little consideration. Yet the importance of emotions has already been proven in the context of academic achievement (e.g., Eysenck, 1992; Schutz \& Pekrun, 2007). So it seems logical that emotions also influence the persistence process.

Despite the obvious impact of striking moments and life events on persistence, they have been little considered in the literature on persistence. However, a student's trajectory is full of different striking moments and events that may affect his academic progress. Considering these moments and events as a part of the student's trajectory calls into question the very linear approaches proposed in the literature to explain the persistence process. Persistence and its determinants are therefore constantly challenged based on what students are experiencing. Theoretical models with feedback loops should therefore be considered in order to reassess the various dimensions of the models based on events experienced. These results also support the idea that there is not only one way to persist.

Our analysis revealed that the experience of these moments and of these events can be transformed by a series of factors included in this persistence process. Specifically, four determinants emerged from our analysis: interest, self-confidence (which can also be considered as self-efficacy), social integration and social support. These factors are well known in the literature on persistence.

Interest seems to be the most central determinant in the process of persistence. Indeed, without interest, persistence seems compromised. These results are not surprising in light of the expectancy-value model (Eccles \& Wigfield, 2002; Wigfield \& Eccles, 2000). Indeed, according to this theoretical model, interest in a task is a key determinant in persisting in the task (Eccles \& Wigfield, 2002; Neuville et al., 2007; Neuville \& Frenay, 2009; Schunk \& Ertmer, 2000). These results also highlight the importance of guidance in the study choice. A choice of study supported and made with certainty increases student motivation and therefore the interest he has in his studies. Consequently, the probability that he will persist increases (Germeijs \& Verschueren, 2006).

Self-efficacy also seems to play an important role. In the literature, self-efficacy is defined as the belief an individual has in his abilities to organize and use different means required to achieve a certain level of success (Bandura, 1997). Several studies and meta-analyses have shown that self-efficacy is highly related to student persistence (Burrus et al., 2013; Robbins et al., 2004; Schmitz et al., 2010; Torres \& Solberg, 2001; Vuong, Brown-Welty, \& Tracz, 2010; Wright, Jenkins-Guarnieri, \& Murdock, 2012). Moreover, Karpanty (1998) and Torres and Solberg (2001) showed that a high sense of self-efficacy was associated with a higher intention to persist. The results of our study are thus not surprising.

Our results also demonstrate that social integration and social support are very important in the student's trajectory. Some researchers have shown that feeling supported and accepted may have an energizing function, which awakens enthusiasm, interest and willingness to participate and engage in academic activities (Cohen, 2004; Furrer \& Skinner, 2003). Students who are less socially integrated are more likely to drop out (Schmitz \& Frenay, 2013). It seems that the benefits of integration are due to the decreased level of stress that social ties can create (Grant, Hamer, \& Steptoe, 2009). Recent studies have shown that social isolation was strongly associated with depression (Shankland, 2012; Wei, Russel, \& Zakalik, 2005). Support also has generally positive effects on persistence for those who benefit from it (Newman, 2002; Ratelle, Larose, Senecal, \& Guay, 2005; Schmitz, Frenay, \& Neuville, 2006). Note however that it is the quality of support that seems to be most important (Cohen, 2004). In the same vein, our interviews suggest that this support is seen by some students as pressure, sometimes guilt-inducing, to persist. In this context, the effects of support seem more negative in terms of well-being, persistence, and also achievement, as evidenced by the testimony of some participants 
in our study. Thus, behind the support and encouragement of relatives, some students feel that their relatives expecting them to continue their studies anyway. This social pressure may be likened to the social pressure associated with injunctive norms. Injunctive norms are defined as the perception of what others think you should do (Cialdini, 2012). In the literature, injunctive norms influence behavior (e.g., Cialdini, 2012; Fishbein \& Ajzen, 2010) and have an impact on persistence (Roland, Frenay, \& Boudrenghien, 2016). These injunctive norms may therefore influence the decision to continue or stop studying. These findings are consistent with work that demonstrates that support encouraging student autonomy leads to more persistence than does controlling support (Deci \& Ryan, 2008; Ratelle et al., 2005).

The four determinants that have emerged from our analyses are all present in educational and motivational models. Specifically, interest and self-efficacy are at the heart of the expectancy-value model while social integration is the central concept of Tinto's model (2006). Finally, the importance of social support has been validated by numerous authors including Bean (1985). As several authors have suggested before, our results indicate that it seems necessary to consider jointly the educational and motivational variables involved in order to better understand persistence (Schmitz et al., 2010; Carbera et al., 1993; Sandler, 2000).

However, our analyses revealed that these determinants did not all have the same role and their influence varied depending on the period of year and / or the events experienced.

Interest and social support are the only factors that operate at all critical moments and during life events. They are therefore central to the persistence process. Self-efficacy occurs only during exams and during the announcement of exam results. However, this is not surprising because it is during moments of doubt and evaluations such as exams that the confidence of students enables them to not give up. Finally, the role of integration seems particularly important when students enter university. This idea is consistent with the literature (Astin, 1993; Hurtado et al., 1996; Upcraft \& Gardner, 1989) which states that it is during the first few weeks at university that social integration develops. The simultaneous presence of all these factors fosters the persistence of the student. Nevertheless we noted that the absence of one of these determinants can be compensated for by the presence of one other determinant that can sometimes offset the negative effects of the absence.

Indeed, we found that among students who have, at some point, had a loss of interest in their studies, the presence of support and the feeling of being integrated were essential to persistence. This can be explained by the fact that the relatedness has a re-mobilizing power among students and reinforces their commitment to their studies (Marks, 2000; Newman, 2002; Schmitz et al., 2006). However, such re-mobilizing effect only occurred with students who have a minimum of interest in their studies. Students who have never had any interest in their studies have not seen this interest improved thanks to the support of their relatives.

For students who are not successfully integrated with their peers, persistence can also be complicated because they are left alone to face the different challenges. The presence of social support outside their academic program helps these students to move forward. This support probably compensates for the lack of integration and provides social contacts necessary for their well-being. Moreover, in case of difficulties, these students can count on relatives and/or old friends to help them. This idea supports research that showed that at university entrance it is important for their persistence that students remain in contact with their past communities, family, church, or tribe (Nora, 2001; Terenzini et al., 1994).

In the absence of support, self-efficacy enables students to persist. This can be explained by the fact that one of the main contributions of support is to give students confidence in themselves and in their abilities to succeed and persist (Lopez, Campbell \& Watkins, 1989; Ryan, Solberg, \& Brown, 1996; Torres \& Solberg, 2001). If this support is absent, it is necessary for students to find this confidence in themselves.

Moreover, students who have low self-efficacy need to be supported to persist. They also need to have interest in their studies. Because of their lack of self-confidence, they probably need to at least have confidence in their study choice.

These results underscore the importance played by support in counterbalancing lack of interest, lack of confidence the lack of social integration. This reinforces the idea that the human being is a social being (Wallon, 1946) for whom the presence of others can overcome a series of difficulties.

These results reinforce once again the idea that persistence is a dynamic process. In addition, they also emphasize the need to take into account the heterogeneity of students (Heikkilä, Niemivirta, Nieminen, \& Lonka, 2011). This idea has already been developed for PhD students' persistence (Devos et al., 2016).

Although the objective of our study was to better understand persistence, we found that we could not speak of the persistence process without mentioning academic achievement or failure. The concepts of achievement and persistence seem related (Roland et al., 2015) and so it seems important to discuss the complex relationship between them. We observe that persistence during the year is a prerequisite for academic achievement (Kern, Fagley, \& Miller, 1998). Thus, students who have put a lot into their studies are more successful. Nevertheless, as much research has shown, 
achievement is also a determinant of persistence (Roland et al., 2015). However, if persistence is necessary for academic achievement, a student who passes his first year does not necessarily persist. Indeed, some students decide to leave the university, even if they are successful. This was particularly the case of A02. In the same vein, persistence does not depend entirely on achievement because a student can persist regardless of achievement, as illustrated by the case of A03. Achievement is nonetheless a facilitator to persistence and may be a necessary condition in the event of repeated failures. Indeed, to persist, a student must be authorized by the institution to continue his studies. To do so, he must comply with administrative conditions to continue his curriculum. In many education systems, a requirement for repeated failures is to have passed at least one year of study. In this case, success becomes a prerequisite for persistence.

This study presents a series of limitations. First, it was conducted with 15 psychology students. The sample size and specificity do not allow us to generalize from our results. It is therefore be necessary to replicate this research with a larger sample. Second, the qualitative approach allowed us to portray the progress of a number of students based on their spoken statements. However, such an approach does not allow us to suggest any causal relationships. It is therefore necessary to remain cautious about interpretations that may result from this research.

\section{References}

Astin, A. W. (1993). What matters in college: Four critical years revisited. San Francisco: Jossey-Bass.

Bandura, A. (1997). Self-Efficacy: The Exercise of Control. New York: Freeman.

Bean, J. P. (1985). Interaction effects based on class level in an explanatory model of college student dropout syndrome. American Educational Research Journal, 22(1), 35-64. https://doi.org/10.3102/00028312022001035

Bean, J. P., \& Metzner, B. S. (1985). A conceptual model of non-traditional undergraduate student attrition. Review of Educational Research, 55(4), 485-540. https://doi.org/10.3102/00346543055004485

Blanchet, A., \& Gotman, A. (2010). L'entretien - L'enquête et ses méthodes ( $2^{\text {nd }}$ ed.). Paris: Armand Colin.

Braun, V., \& Clarke, V. (2006). Using thematic analysis in psychology. Qualitative Research in Psychology, 3(2), 77-101. http://dx.doi.org/10.1191/1478088706qp063oa

Braxton, J. M., Sullivan, A. V. S., \& Johnson, R. M. (1997). Appraising Tinto's theory of college student departure. In J. C. Smart (Ed.), Higher Education: Handbook of Theory and Research (Vol. 12, pp. 107-164). New York: Agathon Press.

Braxton, J.-M., Hirschy, A. S., \& McClendon, S. A. (2004). Understanding and reducing college student departure. San Francisco: Jossey-Bass.

Briggs, A. R. J., Clark, J., \& Hall, I. (2012). Building bridges: Understanding student transition to university. Quality in Higher Education, 18, 3-21. http://dx.doi.org/10.1080/13538322.2011.614468

Burrus, J., Elliott D., Brenneman, M., Markle, R., Carney, L., Moore, G., ... Roberts R. D. (2013). Putting and keeping students on track: Toward a comprehensive model of persistence and goal attainment. Princeton, NJ: Educational Testing Service.

Cabrera, A. F., Nora, A., \& Castaneda, M. B. (1993). College persistence: structural equations modeling test of an integrated model of student retention. The Journal of Higher Education, 64(2), 123-139. https://doi.org/10.2307/2960026

Cialdini, R. B. (2012). The focus theory of normative conduct. In P. A. M. Van Lange, A.W. Kruglanski ,\& E. T. Higgins (Eds.), Handbook of Theories of Social Psychology (pp. 295-311). Thousand Oaks, CA: SAGE. https://doi.org/10.4135/9781446249222.n41

Cohen, S. (2004). Social relationships and health. American Psychologist, 59(8), 676-684. http://dx.doi.org/10.1037/0003-066X.59.8.676

Creswell, J. W. (2003). Research design: qualitative, quantitative, and mixed methods approaches ( $2^{\text {nd }}$ ed.). California: Sage Publications.

De Ketele, J. M., \& Roegiers, X. (2009). Méthodologie du recueil d'informations (4 ${ }^{\text {th }}$ ed.). Bruxelles-Paris : De Boeck Université

Deci, E. L., \& Ryan, R. M. (2008). Self-determination theory: a macro theory of human motivation, development, and health. Canadian Psychology, 49(3), 182-185. http://dx.doi.org/10.1037/a0012801

Eccles, J. S., \& Wigfield, A. (2002). Motivational beliefs, values, and goals. Annual Review of Psychology, 53, 109-132. http://dx.doi.org/10.1146/annurev.psych.53.100901.135153

Eysenck, M. W. (1992). Anxiety: the cognitive perspective. Hove, UK: Erlbaum. 
Fischer, C., \& Wertz, F. (1975). Empirical phenomenological analyses of being criminally victimized. In A. Giorgi (Ed.), Phenomenology and psychological research (pp. 135-158). Pittsburgh: Duquesne University Press.

Fishbein, M., \& Ajzen, I. (2010). Predicting and changing behavior: the reasoned action approach. New York: Psychology Press (Taylor \& Francis).

Furrer, C., \& Skinner, E. (2003). Sense of relatedness as a factor in children's academic engagement and performance. Journal of Educational Psychology, 95(1), 148-162. http://dx.doi.org/10.1037/0022-0663.95.1.148

Gao, Z., \& Xiang, P. (2008). College students' motivation toward weight training: an application of expectancy-value model. Journal of Teaching in Physical Education, 27, 399-415. http://dx.doi.org/10.1123/jtpe.27.3.399

Germeijs, V., \& Verschueren, K. (2006). High school students' career decision-making process: a longitudinal study of one choice. Journal of Vocational Behavior, 68, 189-204. http://dx.doi.org/10.1016/j.jvb.2005.08.004

Grant, M., Hamer, A., \& Steptoe, A. (2009). Social isolation and stress-related cardiovascular, lipid, and cortisol responses. Annals of Behavioral Medicine, 37(1), 29-37. http://dx.doi.org/10.1007/s12160-009-9081-z

Graziano, P. A., Reavis, R. D., Keane, S. P., \& Calkins, S. D. (2007). The role of emotion regulation in children's early academic success. Journal of School Psychology, 45(1), 3-19. http://dx.doi.org/10.1016/j.jsp.2006.09.002

Heikkilä, A., Niemivirta, M., Nieminen, J., \& Lonka, K. (2011). Interrelations among university students'approaches to learning, regulation of learning, and cognitive and attributional strategies: a person oriented approach. Higher Education, 61(5), 513-529. http://dx.doi.org/10.1007/s10734-010-9346-2

Holahan, C. J., \& Moos, R. H. (1981). Social support and psychological distress: a longitudinal analysis. Journal of Abnormal Psychology, 49, 365-370. http://dx.doi.org/10.1037/0021-843X.90.4.365

Holmes, T. H., \& Rahe, R. H. (1967). The social readjustment rating scale. Journal of Psychosomatic research, 11(2), 213-221. http://dx.doi.org/10.1016/0022-3999(67)90010-4

Hurtado, S., Carter, D. F., \& Spuler, A. (1996). Latino student transition to college: assessing difficulties and factors in successful college adjustment. Research in Higher Education, 37(2), 135-157. http://dx.doi.org/10.1007/BF01730113

Kahn, J. H., \& Nauta, M. M. (2001). Social-cognitive predictors of first-year college persistence: the importance of proximal assessment. Research in Higher Education, 42(6), 633-652. http://dx.doi.org/10.1023/A:1012225510213

Kalsner, L., \& Pistole, C. (2003). College adjustment in a multiethnic sample: attachment, separation-individuation, and ethnic identity. Journal of College Student Development, 44(1), 92-109. http://dx.doi.org/10.1353/csd.2003.0006

Karpanty, R. E. (1998). Role of communication apprehension, college self-efficacy, peer integration and faculty integration on college persistence: Unpublished master's thesis. University of Wisconsin-Milwaukee.

Kern, C. W., Fagley, N. S., \& Miller, P. M. (1998). Correlates of college retention and GPA: learning and study strategies, testwiseness, attitudes, and ACT. Journal of College Counseling, 1(1), 26-34. http://dx.doi.org/10.1002/j.2161-1882.1998.tb00121.x

Kuh, G. D., Kinzie, J., Buckley, J. A., Bridges, B. K., \& Hayek, J. C. (2006). What matters to student success: a review of the literature. Commissioned report for the National Symposium on Postsecondary Student Success: Spearheading a dialog on student success. Washington, DC: National Postsecondary Education Cooperative.

Leclerc-Olive, M. (1997). Le dire de l'évènement (biographique). In Villeneuve d'Ascq: Presses Universitaires du Septentrion.

Lopez, F. G., Campbell, V. L., \& Watkins, C. E. (1989). Effects of marital conflict and family coalition patterns on college student adjustment. Journal of College Student Development, 30, 46-52.

Marks, H. M. (2000). Student engagement in instructional activity: patterns in the elementary, middle, and high school years. Amercian Educational Research Journal, 37, 153-184. https://doi.org/10.3102/00028312037001153

McLellan, E., McQueen, K., \& Neidig, J. (2003). Beyond the qualitative interview: Data preparation and transcription. Field Methods, 15(1), 63-84. http://dx.doi.org/10.1177/1525822X02239573

Moos, R. H., \& Swindle, R. (1990). Stressful life circumstances: concepts and measures. Advances in Measuring Life Stress, 6(3), 171-178. http://dx.doi.org/10.1002/smi.2460060302

National Center for Education Statistics (2005). College persistence on the rise? Changes in 5-year degree completion and postsecondary persistence rates between 1994 and 2000 (NCES Statistical Analysis Report 2005-156). Washington, DC, U.S. Department of Education, Office of Educational Research and Improvement.

Neuville, S., \& Frenay, M. (2009). La persistance des étudiants de ler baccalauréat à la lumière du modèle 
expectancy-value. Presentation presented at Réseau de Recherche en éducation et formation (REF), Nantes.

Neuville, S., Frenay, M., \& Bourgeois, E. (2007). Task value, self-efficacy and goal orientations: Impact on self-regulated learning. Psychologica Belgica, 47(1-2), 95-117. https://doi.org/10.5334/pb-47-1-95

Neuville, S., Frenay, M., Noël, B., \& Wertz, V. (2013). Persévérer et réussir à l'université. Louvain-la-Neuve: Presses universitaires de Louvain.

Newman, R. S. (2002). How self-regulated learners cope with academic difficulty: the role of adaptative help seeking. College of Education, 41,132-138. http://dx.doi.org/10.1207/s15430421tip4102_10

Nora, A. (2001). The depiction of significant others in Tinto's "rites of passage": a re-conceptualization of the influence of family and community in the persistence process. Journal of College Student Retention: Research, Theory \& Practice, 3(1), 41-56. http://dx.doi.org/10.2190/BYT5-9F05-7F6M-5YCM

Ogden, J. (2010) Health Psychology: a textbook ( $5^{\text {th }}$ ed.). Open University Press, McGraw Hill.

Organisation de Coopération et de Développement Economiques (OCDE) (2013). Regards sur l'éducation.

Otero, R., Rivas, O., \& Rivera, R. (2007). Predicting persistence of Hispanic students in their first year of college. Journal of Hispanic Higher Education, 6(2), 163-173. http://dx.doi.org/10.1177/1538192706298993

Paillé, P., \& Mucchielli, A. (2012). L'analyse qualitative en sciences humaines et sociales ( $3^{\text {rd }}$ ed.). Paris: Armand Colin. https://doi.org/10.3917/arco.paill.2012.01

Papalia, D., \& Feldman, R. (2014). Experience Human Development (13 ${ }^{\text {th }}$ ed.). Montréal: Chenelière/McGraw-Hill.

Pascarella, E., \& Terenzini, P. (2005). How College Affects Students: A Third Decade of Research (2 ${ }^{\text {nd }}$ ed.). Hoboken, NJ: John Wiley \& Sons.

Ratelle, C. F., Larose, S., Guay, F., \& Senécal, C. (2005). Perceptions of parental involvement and support as predictors of college students' persistence in a science curriculum. Journal of Family Psychology, 19(2), $286-293$. http://dx.doi.org/10.1037/0893-3200.19.2.286

Robbins, S. B., Lauver, K., Le, H., Davis, D., Langley, R., \& Carlstrom, A. (2004). Do psychosocial and study skill factors predict college outcomes? A meta-analysis. Psychological Bulletin, 130(2), 261-288. http://dx.doi.org/10.1037/0033-2909.130.2.261

Roland, N., De Clercq, M., Dupont, S., Parmentier, P., \& Frenay, M. (2015). Vers une meilleure compréhension de la persévérance et de la réussite académique : analyse critique de ces concepts adaptée au contexte belge francophone. Revue Internationale de Pédagogie de l'Enseignement Supérieur, 31(3), 1-16.

Roland, N., Frenay, M., \& Boudrenghien, G. (2015). Identification des croyances associées à la persévérance des étudiants en première année à l'université. Revue des Sciences de l'Education, 41(3), 409-429. https://doi.org/10.7202/1035311ar

Roland, N., Frenay, M., \& Boudrenghien, G. (2016). Understanding academic persistence through the theory of planned behaviour: Normative factors under investigation. Journal of College Student Retention: Research, Theory \& Practice, 15, 1-21.

Ryan, N. E., Solberg, V. S., \& Brown, S. D. (1996). Family dysfunction, parental attachment, and career search self-efficacy among community college students. Journal of Counseling Psychology, 43, 84-89. http://dx.doi.org/10.1037/0022-0167.43.1.84

Salmon, D., Houart, M., \& Slosse, P. (2011). Pourquoi mettre en place des dispositifs d'accompagnement et de remédiation, et comment en évaluer l'efficacité ? In P. Parmentier (Ed.). Recherches et actions en faveur de la réussite en première année universitaire. Vingt ans de collaboration dans la Commission «Réussite »du Conseil interuniversitaire de la Communauté française de Belgique (pp. 32-38). Bruxelles: CIUF

Sandler, M. E. (2000). Career decision-making self-efficacy, perceived stress, and an integrated model of student persistence: a structural model of finances, attitudes, behavior, and career development. Research in Higher Education, 41(5), 537-580. http://dx.doi.org/10.1023/A:1007032525530

Schimtz, J., Frenay, M., \& Neuville, S. (2006). Comprendre la persistance et la réussite en premier baccalauréat. Quel est le rôle des relations sociales entre pairs et des pratiques pédagogiques des enseignants ? In M. Frenay, B. Raucent \& P. Wouters (Eds.). Les activités pédagogiques actives : enjeux et conditions. Louvain-la- Neuve : Presses Universitaires de Louvain.

Schmitz, J., \& Frenay, M. (2013). La persévérance en première année à l'université : rôle des expériences en classe, de l'intégration sociale et de l'ajustement émotionnel. In S. Neuville, M. Frenay, B. Noël \& V. Wertz (Eds.). Persévérer et réussir à l'Université. Louvain-la-Neuve: Presses universitaires de Louvain. 
Schmitz, J., Frenay, M., Neuville, S., Boudrenghien, G., Wertz, V., Noël, B., \& Eccles, J. (2010). Etude de trois facteurs clés pour comprendre la persévérance à l'université. Revue française de pédagogie, 172, 43-61. https://doi.org/10.4000/rfp.2217

Schunk, D. H., \& Ertmer, P. A. (2000). Self-regulation and academic learning: self-efficacy enhancing interventions. In M. Boekaerts, Pintrich, P. R., \& Zeidner, M. (Eds.), Handbook of self-regulation (pp. 631-649). San Diego, CA: Academic Press. https://doi.org/10.1016/B978-012109890-2/50048-2

Schutz, P. A., \& Pekrun, R. (2007). Emotion in Education. Amsterdam: Academic Press.

Shankland, R. (2012). Bien-être: le rôle de la gratitude, psychologue positive et bien-être au travail, Issty-les-Moulineaux, France : Elsevier Masson.

Terenzini, P. T., Rendon, L. I., Upcraft, M. L., Millar, S. B., Allison, K. A., Gregg, P. L.,.... (1994). The transition to college: diverse students, diverse stories. Research in Higher Education, 35(1), 57-73. http://dx.doi.org/10.1007/BF02496662

Tinto, V. (1975). Dropout from higher education: a theoretical synthesis of recent research. Review of Educational Research, 45(1), 89-125. http://dx.doi.org/10.3102/00346543045001089

Tinto, V. (1997). Classrooms as communities. Exploring the educational character of student persistence. Journal of higher education, 68(6), 599-623. http://dx.doi.org/10.2307/2959965

Tinto, V. (2006). Research and practice of student retention: what next? Journal of College student retention, 8(1). 1-19. http://dx.doi.org/10.2190/4YNU-4TMB-22DJ-AN4W

Torres, J., \& Solberg, S. (2001). Role of self-efficacy, stress, social integration, and family support in Latino college student persistence and health. Journal of Vocational Behavior, 59, 53-63. http://dx.doi.org/10.1006/jvbe.2000.1785

Upcraft, M., \& Gardner, J. (1989). A comprehensive approach to enhancing freshman success. In M. Upcraft, \& J. Gardner (Eds.), The freshman year experience: helping students to survive and succeed in college (pp. 1-15). San Francisco Jossey-Bass.

Vuong, M., Brown-Welty, S., \& Tracz, S. (2010). The effects of self-efficacy on academic success of first-generation college sophomore students. Journal of College Student Development, 51(1), 50-64. http://dx.doi.org/10.1353/csd.0.0109

Wallon, H. (1946). Le rôle de l'autre dans la conscience du moi. Psychologie et Éducation de l'Enfance, 3(12), 277-286.

Wasylkiw, L. (2016). Students' perspectives on pathways to university readiness and adjustment. Journal of Education and Training Studies, 3(4), 28-39. http://dx.doi.org/10.11114/jets.v4i3.1197

Wei, M., Russell, D. W., \& Zakalik, R. A. (2005). Adult attachment, social self-efficacy, self-disclosure, loneliness, and subsequent depression for freshmen college students: A longitudinal study. Journal of Counseling Psychology, 52, 602-614. http://dx.doi.org/10.1037/0022-0167.52.4.602

Wigfield, A., \& Eccles, J. (2000). Expectancy-value theory of achievement motivation. Contemporary Educational Psychology, 25(1), 68-81. http://dx.doi.org/10.1006/ceps.1999.1015

Willig, C. (2013). Introducing qualitative research in psychology ( $3^{\text {rd }}$ ed.). Berkshire: Open University Press.

Wright, S. L., Jenkins-Guarnieri, M. A., \& Murdock, J. L. (2012). Career development among first-year college students: college self-efficacy, student persistence, and academic success. Journal of Career Development, 40(4), 292-310. http://dx.doi.org/10.1177/0894845312455509

This work is licensed under a Creative Commons Attribution 3.0 License. 